\title{
Black Christ and Cross-Roads Jesus for white South African Christians
}



A significant factor undermining real racial reconciliation in post-1994 South Africa is widespread resistance to shared historical responsibility amongst South Africans racialised as white. In response to the need for localised 'white work' (raising self-critical, intragroup historical awareness for the sake of deepened racial reconciliation), this article aims to contribute to the uprooting of white denialism, specifically amongst Afrikaans-speaking Christians from (Dutch) Reformed backgrounds. The point of entry is two underexplored, challenging, contextualised crucifixion paintings, namely, Black Christ and Cross-Roads Jesus. Drawing on critical whiteness studies, extensive local and international experience as a 'participatory' facilitator of conflict transformation and his particular embodiment, the author explores the creative unsettling potential of these two prophetic 'icons'. Through this incarnational, phenomenological, diagnostic engagement with Black Christ, attention is drawn to the dynamics of family betrayal, 'moral injury' and idolisation underlying 'white fragility'. 'White fatigue' is challenged by stressing the Biblical nature of Cross-Roads Jesus' confrontational, 'ugly' portrayal of the systemic violence of apartheid and colonialism. It is also argued that a combination of Louw's shocking portrayal of an enraged, emaciated township Jesus with the explicit depiction of white historical responsibility in Black Christ increases the counter-cultural potential of these icons to disrupt denial amongst white South African Christians. However, the realisation of this potential will require the cultivation of more capacity to work creatively with the intense emotional, moral, spiritual discomfort brought to the surface by this type of religious icon.

Contribution: The article argues for a contextualised, South African engagement with the crucifixion of Christ, through an embodied interpretation of two anti-apartheid religious paintings. It makes a contribution to critical whiteness studies and practical theology and thus fits into the interdisciplinary, hermeneutical scope of HTS.

Keywords: racial reconciliation; white denial; white fragility; white fatigue; family betrayal; moral injury; shared responsibility; systemic violence; religious icons; black Christology.

\section{Reluctant encounters with Black Christ and Cross-Roads Jesus}

How could a government that professed to be Christian perpetrate such immoral deeds and inflict so much pain and suffering on its own countrymen simply because [they] were of another race, another colour, another creed? (Harrison 2006:25)

This question haunted a 21-year-old Ron Harrison towards the end of 1961. One evening 'a thought flashed through' his head (Harrison 2006):

[Prime Minister] Verwoerd and [Minister of Justice] Vorster were wreaking havoc in their quest for white supremacy and Afrikaner domination, and in the process ... all races that were not classified 'white' were being crucified. (p. 25)

In his autobiography, Harrison (2006) describes the 'birth of the Black Christ':

The picture of a suffering Christ at the scene of His crucifixion surged through my mind, but the vision forming in my mind's eye was rather unusual in that the figure on the cross was a black man! I realised that I could depict the suffering of the black people and equate this with the suffering of Christ. Who better [for my Christ figure] than Chief Albert Luthuli, who had just been awarded the Nobel Peace Prize ... I decided that the architects of apartheid also had to be brought into the scene. I had it! Verwoerd and Vorster would be portrayed as two Roman centurions, the tormentors of Christ. Verwoerd would be piercing the side of Christ, and his henchman, Vorster, would be standing with the sponge of vinegar and gall. A coloured Madonna and an Asian St John would complete the scene. (pp. 25-26)

1.For more on the historical context, see Davenport (1986), Kenney (1980) and Biko (2012) 


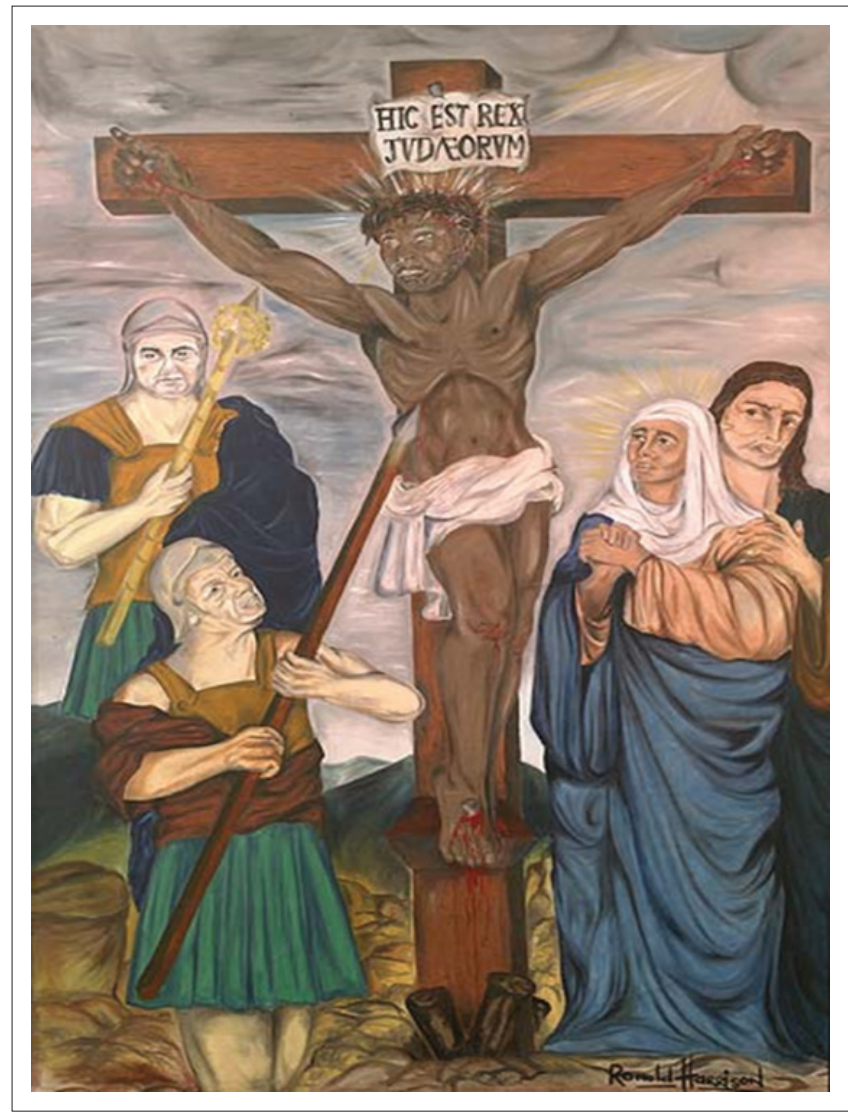

Source: Harrison, R., 2006, The Black Christ: A journey of freedom, David Philip, Cape Town FIGURE 1: The Black Christ.

Though widely welcomed in anti-apartheid church circles, the white Dutch Reformed Church (DRC) mouthpiece, Die Kerkbode, condemned Black Christ as blasphemous and the major Afrikaner newspaper Die Burger called for its banning. Following an official complaint from the DRC, the Censorship Board declared Black Christ 'unfit for public exhibition' because it 'gave offence to the religious convictions and feelings of a section of the population' (De Gruchy 2001:230). By then, the provocative protest art work was smuggled out to the United Kingdom where it was used for a number of years to raise awareness and funds for the anti-apartheid struggle (see Figure 1).

Harrison was repeatedly and brutally interrogated and tortured to reveal the whereabouts of his painting, leaving permanent damage to his health. The painting was eventually returned to South Africa in 1997 (De Gruchy 2001:230-232; Harrison 2006).

My first encounter with Black Christ was at this point. While I was working in the Truth and Reconciliation Commission (TRC) office in Cape Town, I regularly attended services in 'St. Georges'. After a special reconciliation service, my attention was drawn to a big painting in one corner of the cathedral. It was indeed unusual to see the Christ figure depicted as a black person rather than the typical Western portrayal of a 'whitey in a nightie' (Harrison 2006:26). I recognised the face of Chief Luthuli. But my eyes were irresistibly drawn to a figure in the bottom left corner: a white soldier with a long spear piercing the side of the black figure on the cross. This Roman centurion had a disturbingly familiar face. Pictures, paintings and statutes of a revered Prime Minister Verwoerd featured prominently in my Afrikaner Nationalist upbringing.

But we were not only members of the same 'white tribe', the Afrikaners. We also belonged to the same church, the DRC. Moreover, Dr H.F. Verwoerd is Oupa Hendrik, my grandfather.

By the time I encountered Black Christ in 1997, I had already embarked on ajourney of political and religious transformation away from my earlier enthusiastic, ethnocentric membership of the DRC and proud belonging to the Verwoerd family (Verwoerd 1997). Still, the image of Verwoerd as the person piercing the side of Luthuli was upsetting. More than 20 years after this first encounter, an unwelcome part of me is still recoiling from the prophetic truth of this apartheid era crucifixion scene.

My current experience as a facilitator of racial reconciliation sadly confirms that my persistent inner resistance is quite widespread amongst white South Africans, especially within the DRC. ${ }^{2}$ This (white, DRC) discomfort with contextualised crucifixion is significantly amplified by a more recent painting.

I encountered this shocking painting a few years ago in an unexpected, highly symbolic place: as part of a 'Cross-Roads' exhibition, outside the Chapel of the Faculty of Theology at Stellenbosch University - the historical training ground of DRC ministers, the main birthplace of the theology of apartheid. At first, I could not believe my eyes when I saw the name of the painter and the date it was painted - 'D Louw 91'.

Daniël Louw was my (white, Afrikaans-speaking) pastoral theology professor in the early 1980s; 1990-1993 was the period that witnessed the most violent phase of South Africa's transition to democracy, with many townships surrounding Cape Town literally burning, including Cross Roads, on the outskirts of Khayelitsha.

As was the case with my 1997 encounter with Black Christ, my initial reaction to Louw's series of contextualised crucifixion paintings was mixed. I was deeply grateful that at last someone from within the white DRC circle brought the historical Crucifixion unambiguously into our South African context. But I also felt a surprisingly strong urge to look away, especially from the above painting with the Matthew 27:45 subscript. Despite major pondering of Black Christ, I still felt unprepared to face an emaciated, naked, enraged Christ, in a setting of a burning Cross Roads township, a stone's throw from Stellenbosch. In an interview on 02 May 2019, Louw

2.For example, in a 2017 South African social attitudes survey conducted by the Human Sciences Research Council (HSRC), $64.8 \%$ of white South Africans disagreed or strongly disagreed with this question: '[i]t is essential that all white South Africans take action disagreed with this question: '[i]t is essential that all white South Africans take action towards repairing the damages of the past'. Similar findings can be found in the Institute for Justice and Reconciliation's Reconciliation Barometer (www.ijrorg.za). My view on ongoing white DRC resistance is shaped by intense facilitation involvement over the last 2 years with a growing group of more than 20 younger generation ministers, mostly in the Western Cape, struggling with racial reconciliation in their contexts of overwhelmingly white, Afrikaans-speaking, older congregations. See https://kerkbode. christians.co.za/2019/05/14/versoening-ek-kan-nie-nie-hierby-betrokke-raak-nie, and Schoeman (2010), Jansen (2009) and Van der Westhuizen (2016). 
confirmed, as I expected, that my averse reaction is very typical amongst viewers from similar DRC backgrounds.

In this article, I take a closer look at this highly problematic tendency to look away when someone with my kind of racialised identity is confronted with paintings such Ron Harrison's Black Christ and Daniël Louw's Cross-Roads Jesus. ${ }^{3} \mathrm{I}$ approach these two paintings as (religious) 'icons' - as part of a long tradition of expressing contemporary faith through an 'imaging' of the 'unseen' (Louw 2014). ${ }^{4}$ In the process, I explore their potential to bring often denied, typically repressed intrapersonal and intragroup dynamics to the surface that are undermining real reconciliation in post-1994 South Africa.

My embodied, incarnational approach to these religious icons is mainly shaped by my professional experience as a 'participatory facilitator' of racial reconciliation and transformation in contemporary South Africa. ${ }^{5}$ In thus working through some of my own inner resistance to Black Christ and Cross-Roads Jesus, I wish to clarify some of the less visible sources of white (Afrikaner, DRC) resistance to shared historical responsibility. This diagnostic, phenomenological exercise is intended as a contribution to contextualised 'white work' ${ }^{6}$

I understand this multidimensional process as the cultivation of an embodied, self-critical awareness of the individual and systemic, the visible and invisible pain linked to 'whiteness' to my ongoing 'structurally privileged positionality' as a white South African (Steyn 2012:11). In my experience, doing this kind of social justice work certainly requires uprooting what DiAngelo (2011) defined in the US context as 'white fragility':

$[A]$ state in which even a minimum amount of racial stress becomes intolerable, triggering a range of defensive moves. These moves include the outward display of emotions such as anger, fear, and guilt, and behaviours such as argumentation, silence,

3.The full title of Louw's series of contextualised paintings is: "Towards a Theology of the Cross: Cross-Roads/Kruis-pad'. I use the title 'Cross-Roads Jesus' as a succinct way to refer to the particular painting I am concentrating on in this article.

4.My approach has also been shaped by De Gruchy's (2008:26-30) careful reclaiming of (Orthodox) icons as a 'means of grace', given the iconoclastic tendency in of (Orthodox) icons as a "means of grace, given the iconoclastic tendency in Louw's re-appreciation of the aesthetic dimension of theology and genuine spirituality and the transformative potential of art (De Gruchy 2001; Louw 2014).

5.This participatory approach to facilitation means, firstly, that I cannot expect participants to go to difficult places if I am not willing to do that myself. That is, cannot expect others from similar cultural-religious backgrounds to face the full truth of these icons if I am not prepared to do this myself. Secondly, being a participatory facilitator challenges the claim that a facilitator can be neutral; it is important explicitly to accept one's positionality and that this is an inescapable part of a group process. For example, it is impossible for me to be a facilitator of inclusive storytelling and For example, it is impossible for me to be a facilitator of inclusive storytelling and dialogue in a South African context if I am not willing to be open and to be challenged by participants given the heavy, painful baggage that enters the room with the colou of my skin, my masculinity, my age and my historically charged surname. I weave thi awareness of my positionality into my reflective engagement with two demanding prophetic paintings. The third aspect of being a participatory facilitator that lies behind my approach in this article is the experience of using one's inner dynamics during a group process as a reliable guideline, as a lightning rod to sense what is really going on. In similar vein, I use my own mixed reactions to these religious icons as a window on negative emotional reactions amongst white South African Christians, especially from DRC backgrounds. This participatory facilitation approach has been formed by international experience as a full-time peace practitioner between 2002 and 2012, mostly in the context of the conflict in and about Northern Ireland but also in Israel-Palestine (see Little \& Verwoerd 2013). Since returning to South Africa at the end of 2012, I have worked as a facilitator with a range of groups.

6.I am drawing on the large literature on 'whiteness' within critical race theory (e.g. DiAngelo 2011; Frankenberg 1993). I resonate in particular with the South African focussed work of Melissa Steyn (2001, 2012). Steyn (2012:11) defines 'whiteness' as .... a structurally privileged positionality (un)informed by ignorance/blindnesses taking for granted unearned entitlements that come at the expense of racialized others, and generally lacking insight into the normalized racial order that shapes life others, and generally lacking insight into the normalized racial order that shapes life opportunities and conditions imperceptibly around the comfort, convenience and
advancement of whites'. See also the work of Christi van der Westhuizen $(2016,2017)$.

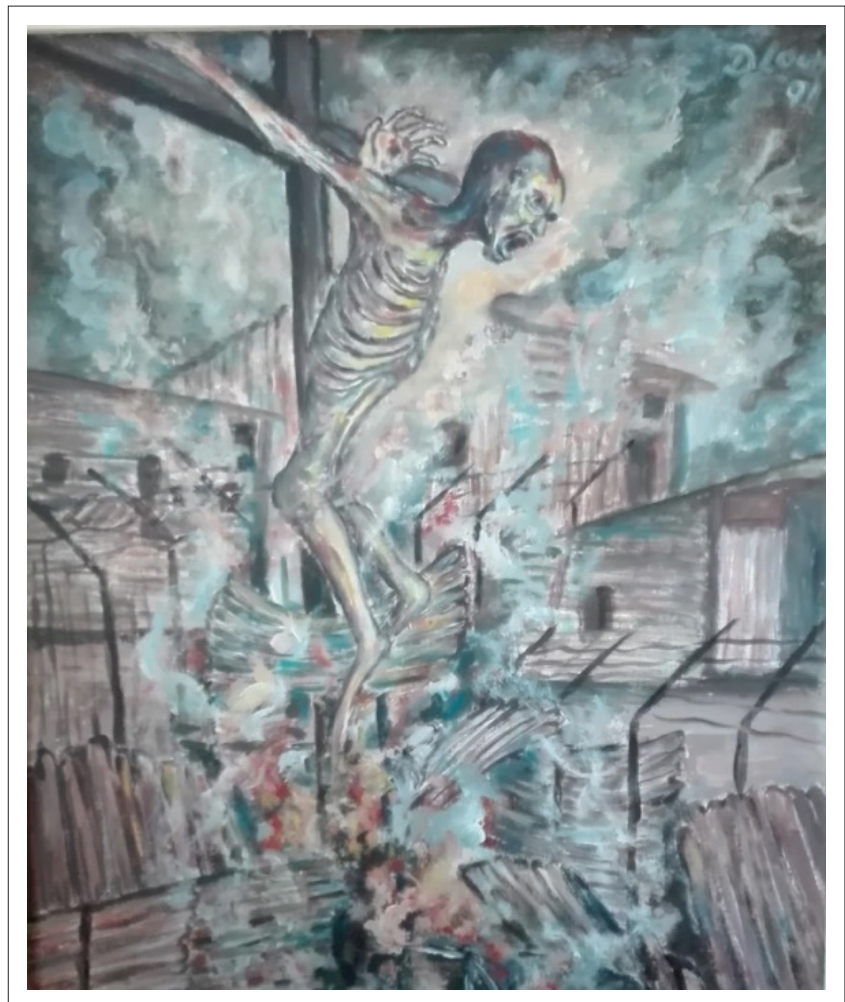

Source: Louw, D.L., 2014, Icons: Imaging the unseen, SUN Press, Stellenbosch

FIGURE 2: 'My God, my God, why have you forsaken me?' (Mt 27:45).

and leaving the stress-inducing situation. These behaviours, in turn, function to reinstate white racial equilibrium. (p. 54)

Another diagnostic concept from antiracism white work in the US (tertiary education) context which I find particularly useful is 'white fatigue' (Flynn 2015):

[T] he dynamic of White students who intuitively recognize the moral imperative of antiracism (primarily viewed as individual racism); however, they $[d o]$ not fully understand ... [how] racism functions as an institutional and systemic phenomenon. Due to the complexity required of critical (as compared to simplistic) studies of racism, those who are fatigued claim to be 'tired of talking about' racism, despite the intuitive understanding that racism is morally wrong. (p. 115)

Broadly speaking, the key question raised for me by critical whiteness studies is as follows: how can I, and those who share the racialised part of my sociopolitical identity, use the persistent power and privilege associated with being a white South African to contribute to the transformation rather than the transmission of whiteness? That is, how can I participate in overcoming 'white fragility' and 'white fatigue' in South Africa? How can I stop running away from the deeply rooted historical pain represented by the colour of my skin? ${ }^{7}$

7.See also my response to John De Gruchy's 8th Steve de Gruchy Memorial Lecture (Verwoerd 2019a). Like De Gruchy, I am aware of the pitfall of essentialising racialised (or gendered) identities. While recognising intersectional complexity racialised (or gendered) identities. 'While recognising intersectional complexity amongst those formerly classified as 'white', lagree with him that given the legacies of systematic racial discrimination in South Africa under colonialism and apartheid it does make sense to still talk in a generalising fashion about 'white South Africans'. On a call for the transformation of white and black identity in South Africa, see
Beyers (2019). On the interplay between race and gender within Black Theology, see Beyers (2019). On the interplay between race and gender within Black Theology, see
Grant (1989); and on gender, race and class, see Douglas (1994). On the pitfalls of 'single identity' intragroup work, see Church, Visser and Johnson (2004:273-291). 
In this article, my focus is on some of the theological and spiritual dimensions of this kind of white work that aims at transforming the tendency amongst historically privileged white Christians to 'sever the connection between the Cross of Christ and the ongoing crosses of history' (Pretorius 2018:9, drawing on Rambo 2017:75-80). I begin to respond to black theologians' call for an incarnational imagination 'to relate the message of the cross to one's own social reality, to see that "they [we] are crucifying again the Son of God" (Heb 6:6)' (Cone 2017:158; Mofokeng 1983; Williams 2014). ${ }^{8}$

Given the potential of being overwhelmed by an openhearted engagement with this profound challenge, I find it helpful not to become too absorbed in my particular ethnoracial-religious embodiment - to remember that white Afrikaner, DRC Christians are, tragically, the rule rather than the exception (De Gruchy 2006):

As a result of centuries of crusades and wars, pogroms, the Holocaust, racism and oppression, justified by Christians as the will of God and pursued under the banner of the cross, Christians have crucified Jesus afresh. (p. 134)

However, this kind of universalisation by someone from a white DRC background can easily become another layer of avoiding particular historical responsibility in post-1994 South Africa. This pitfall of zooming out too soon and too easily brings me back to the unsettling specificity of Black Christ and, especially, the spear-wielding centurion. ${ }^{9}$

\section{Resisting Black Christ Verwoerd centurion and the dynamics of family betrayal}

The most obvious explanation for my unwelcome inner resistance to Black Christ is on display in a very different picture of the centurion-with-a-spear: me as a 6-month-old baby on the lap of a smiling Oupa Hendrik, being fed by him with a milk bottle. ${ }^{10}$ But being a 'blood relative' is an insufficient explanation as suggested by that milk bottle. This milk can be seen as a rather explicit symbol of Jansen's (2009) often unconscious 'knowledge in the blood' transmitted via my genealogical, cultural and religious 'families'. I must face the likelihood that what I metaphorically received 'with my Oupa's milk' - including my father's unbreakable loyalty to his father - probably soaked more fully into the marrow of my bones than I would like to acknowledge.

In my facilitation work with younger white South Africans, I regularly encounter a similar dynamic of intergenerational loyalty. As a white Afrikaans-speaking theology student

8.1 stand on the shoulders of many earlier critics of the DRC, such as Beyers Naude and Kritzinger (1988), Kinghorn (ed. 1986) and Boesak (1984), and I am indebted to a younger generation of prophetic scholars, for example, Van Wyngaard (2011). On the wider historical complicity of white South African Christianity, see Kleinschmidt (ed. 1972); TRC Report, vol. 4.

9.See also Krondorfer (2015) on the importance of 'unsettling empathy', another potential strand to the conceptual framework for what I am attempting in this article.

10. Huisgenoot photo of $\mathrm{Dr}$ and Mrs Verwoerd with their grandchildren, taken on 08 September 1964, on the porch of Libertas, then official residence of the Prime Minister. succinctly put it during a recent workshop on reconciliation: 'I am tired of talking about apartheid. I am tired to hear that my dad was bad'.

My international peace work has taught me, however, that a more edgy, deeper kind of blood tie is also behind my problematic inner resistance to Harrison's depiction of Verwoerd. A close look at the oupa-with-a-milk-bottle family picture will not show visible scarring on Verwoerd's face, even though a few years before this picture was taken, on 09 April 1960, he was shot twice in the face, at point blank range by David Pratt. His full recovery was a medical rarity and unsurprisingly was interpreted by religious family, friends and followers as a 'miracle from God'. Two years after the milk bottle photo was taken, on 06 September 1966, Prime Minister Verwoerd was assassinated by Dimitri Tsafendas in Parliament (Dousemetzis 2018).

Amongst his many supporters, his death was sanctified - 'he sacrificed his life for our volk'. This inherited, inner circle meaning given to the spilled lifeblood of a beloved leader became an invisible, 'sacred bond' between Verwoerd and his followers (Verwoerd 2019b). It is this bond that probably is the main source of my persistent reluctance to name the political blood on his hands. For this naming feels like a betrayal.

Based on more than a decade of intense engagement with the life journeys of military veterans who became peacemakers, I am pretty sure that this feeling of disloyalty when I criticise my grandfather as a political leader, and my experience of being accused of being a traitor by my father, is not unique. In fact, one of the central themes emerging from an international research project with former combatants and survivors is the multi-layered dynamics of betrayal involved in growing compassion for one's (former) political enemies (Margalit 2002, 2017; Verwoerd \& Little 2018)..$^{11}$

Being confronted with this widespread dynamics of betrayal opened my eyes to the significance of Harrison's depiction of Verwoerd and Vorster as soldiers, especially in the context of doing white work in South Africa today. The faces are those of (elderly) political leaders, but their (young) soldier bodies point to those hundreds of thousands of white men who were conscripted during the apartheid era. Given the much greater needs and suffering of those on the receiving end of generations of systemic racial discrimination, it is, of course, understandable that the post-1994 national focus has not been on the 'lingering, unspoken pain of white youth who fought for Apartheid' (Edlmann 2015, 2012). Here, I am only drawing attention to the strong possibility of a family-type loyalty between white conscripts as 'blood brothers', as 'brothers-inarms', especially towards those who 'paid the ultimate price with their lives'. Aided by Black Christ and my own troubled and troubling reactions to the centurion-with-a-spear figure

11.I co-ordinated and co-facilitated this Beyond Dehumanisation project between 2012 and 2014, with Alistair Little and Brandon Hamber. It involved a series of reflective workshops and interviews, in South Africa, Ireland-Northern Ireland and reflective workshops and interviews, in South Africa, Ireland-Northern Ireland and
Israel-Palestine, with small, diverse groups of (mostly) former combatants or veterans who became peacemakers. 
in this icon, I am suggesting that this kind of fraternal loyalty has become a hidden, politically incorrect source of resistance to genuine racial reconciliation in South Africa.

The spearing of the Luthuli figure in this religious icon can surface further under-recognised roots of white South African 'fragility', especially amongst those who take their Christian faith seriously.

\section{A crucified Luthuli, 'moral injury' and the idolisation of Verwoerd}

Why is it so painful for me to really look at Black Christ? Some of this pain has obviously to do with my reformed, antiapartheid self's empathetic connection with the visible, bloodied point of the spear, with the blood on Luthuli's hands and feet and head - the 'suffering with' of (growing) cross-border compassion for those on the receiving end of the multi-layered violence of apartheid (Gobodo-Madikizela 2016; Verwoerd 2018).

Some of my intense inner discomfort before Black Christ furthermore arises from moral emotions of guilt and, especially, shame evoked by accepting that I also held that spear. ${ }^{12}$ But I sense that there is yet a deeper kind of (selfinflicted) pain at stake.

In working with ex-combatants from the conflicts in and about Northern Ireland, Israel-Palestine and from the USA, I became intensely aware of the human cost of direct involvement in violence (Little \& Verwoerd 2013; Little \& Scott 2009). Especially in the US context, the language of 'moral injury' has become prominent to try and capture an inner wounding, a soul-scarring that goes deeper than psychological damage. 'Moral injury' usually designates (Meagher 2014):

[T] he violation, by oneself or another, of a personally embedded moral code or value resulting in deep injury to the psyche or soul. It is what used to be called sin. (pp. xvi-xvii) ${ }^{13}$

Drawing on his academic training as a classicist and many years of helping to address the moral injuries of US veterans, Meagher carefully applies ancient notions of (moral) pollution ('miasma') in his nuanced critique of the just war tradition. Given my personal and professional journeys, I resonate with his claim that the killing of another human being leaves 'blood' not only on the hands of the killer (even if the killing was not intended). Morally and spiritually speaking, the hands of those who directed and supported the killing are also stained. ${ }^{14}$

When I look at Black Christ through the lens of 'moral injury', I see an invisible part of the spear, the sharp point at the

12.On guilt as a moral emotion associated with particular actions in contrast to shame arising from a sense of failure in one's being, see Klaassen (2001).

13.See also Eyerman (2018) on 'perpetrator trauma'. Typical war-related moral injuries include the witnessing of or being involved in the killing of children and women, even if the soldier believes in the rightness of his side's overall cause.

14.An obvious pitfall with this relational approach to responsibility is destructive guilt by association, as demonstrated by cases of 'ethnic cleansing' and blood feuds (Govier \& Verwoerd 2011) bottom end, which actually is deeply buried in the soldier figure. I am aware of that part of the apartheid spear because I can feel it entangled in my guts. My hunch is that the repression of this pain - the violation of our core moral and religious values by the political system we supported (and still benefit from) - lies at the heart of the (ongoing) 'banning' of Harisson's painting from white Afrikaner enclaves, such as large sections of the DRC (Schoeman 2010; Van der Westhuizen 2016). For Harrison's visual comparison between the apartheid era suppression of 'non-Whites' and the crucifixion of Jesus enabled his prophetic critique to transcend political and moral denunciation, to bring perhaps the deepest wounding of those represented by the Luthuli figure to the surface. As archbishop Desmond Tutu put it in his preface to Steve Biko's classic I Write What I like (Biko 2012):

[T] he most awful aspect of oppression and injustice was not the untold suffering it visited on its victims and survivors ... No, it was the fact that apartheid could ... actually make many of them doubt whether they were indeed God's children. That I have described as almost the ultimate blasphemy. (p. ix $)^{15}$

In this regard, I am struck by how Reformed Black Christ is, at least according to Wolterstorff's interpretation of Calvin's theology of social justice (see also De Gruchy 1991). He stresses that for Calvin claims of love and justice towards other human beings are grounded in the inalienable iconicity of all human beings as being created 'in the image of God'. Therefore, 'to treat unjustly one of these human earthlings in whom God delights is to bring sorrow to God. To wound his beloved is to wound him' (Wolterstorff 1987:20). Calvin's discussion of the Eucharist brings Christ explicitly into this radical picture (Institutes IV 8:38, quoted in Wolterstorff 1987):

We shall benefit very much from the Sacrament if this thought is impressed and engraved on our minds that none of the brethren can be injured, despised, rejected, abused or in any way offended by us without at the same time injuring, despising and abusing Christ by the wrongs we do. (p. 20)

In other words, Harrison's painting presents a radical questioning of Christian Afrikaner Nationalism. It confronts someone like me with a profound, painful truth: what Verwoerd and his supporters did to Luthuli and his people, we also did to Christ (Mt 25:38-40; Ac 9:4-5); even though I was sincere in my Dutch Reformed, 'Afrikaner Calvinist' (De Gruchy 1991) following of (a white) Jesus, I thus remain complicit in the deepest wounding of fellow human beings, and therefore, the re-crucifixion of Christ. In our idolisation of ethno-racial identity, 'my people' and I not only betrayed darker skinned brothers and sisters. We broke the first commandment. We betrayed God.

This conclusion shines a deeply ironic light on the iconoclastic critique of Black Christ in DRC circles. The (tragic) hypocrisy of accusing Harrison of 'blasphemy', the real idolatry behind

15.Se the reference to Biko as a Christlike 'icon' in Lentz and Gateley (2003), Christ in the Margins, quoted in De Gruchy (2008:140) - 'those who serve the poor, struggle for justice and peace, and live lives of compassion, also reflect who Christ is for us, today'. 
white Afrikaner indignation about Verwoerd-as-centurion, was starkly brought home to me during the writing of Verwoerd: My Journey through Family Betrayals (2019b). Sifting through cupboards in the Dr H.F. Verwoerd Memorial House in Orania, I came across this surprisingly self-critical entry in an unpublished diary kept by Ouma Betsie Verwoerd (02 Feb. 1976):

Sin as superstition and doubt - especially: 'A creature can never replace God, since he is a mere creature'. [no source given] So many people then said [after the 6 Sept. 1966 assassination], some till today, that $H$. [Hendrik] was taken away from us because our people trusted too much in him - actually 'the honour/glory solely due to God was given to a creature'. They said so easily: 'I am not worried, V. [Verwoerd] will know what to do.' I never wanted to accept idolisation [verafgoding] as an explanation for his death, never wanted to believe that he was trusted so absolutely. But this morning's reading rattled me: is it not perhaps true?

\section{A long spear of shared responsibility}

Given the risk of a depoliticising individualisation in the use of the language of 'moral injury' and the temptation of scapegoating, I want to conclude this section on Black Christ with one more brief look at the Verwoerd-centurion with the long spear.

This figure can also be seen as a representation of shared responsibility. As mentioned above, a close look reveals the elderly, wrinkled face of an elected, revered or hated political leader, but the body is that of a muscular, youthful soldier. For me, this unusual combination has become a warning against a too easy, self-interested blaming of a particular political leader. I do acknowledge the large individual responsibility H.F. Verwoerd carries as former Minister of 'Native Affairs' (1950-1958) and Prime Minister (1958-1966). I also accept that the most visible faces of the apartheid state, apart from political leaders like Verwoerd, were fellow Afrikaners in the bureaucracy and the police. But there were many other white South Africans who, in effect, were also holding on to that long spear.

As a former South African Defence Force (SADF) colonel, Craig Williamson, aptly put it at the TRC Military Forces hearing (quoted in TRC Report, 1998, vol. 1):

South Africa's weapons, ammunition, uniforms, vehicles, radios and other equipment were all developed and provided by industry. South Africa's finances and banking were controlled by institutions that went so far as to provide covert credit cards for covert operations. South African chaplains prayed for 'victory' and South African schools and universities educated for war. The media carried propaganda and the enfranchised white community voted the former government back into power, time after time, with ever-increasing majorities. (p. 131)

While this quote is useful to stress the spiral of (underacknowledged) moral and political responsibility shared by (most) white South Africans during the apartheid era (Rothberg 2019; Verwoerd 2001), it also highlights the limited scope of the TRC's mandate. To make the deeply rooted systemic violence of apartheid and colonialism and the dehumanising ongoing impact of racialised poverty more visible, I want to turn to Louw's profoundly disturbing CrossRoads Jesus.

\section{Recoiling from Cross-Roads Jesus}

Despite my intensely personal connection with Harrison's Black Christ, I find it much more difficult open heartedly to face the Cross-Roads Jesus icon. Harrison's contextualisation still retained a number of familiar biblical references to the crucifixion of Jesus of Nazareth - the Roman centurions, the figures of Mary and John, the 'King of the Jews' inscription. Moreover, the suffering of Luthuli is softened by the white cloth, the youthful muscularity of his body and the heavenwards glance that radiates serenity, prefiguring the resurrection victory over death, including apartheid (Harrison 2006; Luthuli 2006). The raw, naked intensity of Louw's Jesus figure, within an unambiguous contemporary township setting, feels like a punch in the stomach; it leaves me winded, again and again. I remain sorely tempted to run away from this skeletal, enraged Jesus. A deep part of me rebels against seeing Christ in this figure, torturously straining to break free from the soul-destroying, relentless, godforsaken violence of racialised poverty that continues to encircle white, middleclass Stellenbosch. ${ }^{16}$

During my 2019 interview with Louw, I learnt that this visceral impact was his primary intention:

I wanted to shock white students and colleagues at Stellenbosch University. When you look at this painting you should say, 'I don't want to look at this!' You should go to bed disturbed, thinking 'this does not fit my understanding of God'.

He has exhibited this painting in a number of DRC settings and the 'average church person hates it', the typical commentary is 'I've never seen something as ugly as this'.

I was relieved to hear that he did not only intend a universally applicable theological message with his series of Cross-Roads paintings - affirming 'God's identification with the vulnerability of suffering human beings', opposing 'destructive domination', with the 'dying Son of God' killed 'by all forms of oppressive imperialism' (Louw 2014:24). The specific South African political context also mattered to him in the early 1990s and still does. Under a similar painting of 'township crucifixion', he refers to a 'necklaced Christ' as the 'victim of Roman soldiers (apartheid policy makers) within the hell of township life' (Louw 2014:24). I shared with him what I experience as the overwhelming message of Cross-Roads Jesus: here is a white, Afrikaans-speaking professor from the Kweekskool [Theological Seminary], who, in 1991, wanted to shake his people awake 'listen, listen! We are crucifying Christ again with what we are doing to black South Africans!' Standing next to me in front of his prophetic visual outcry, Louw confirmed that conveying this kind of message was also his intention with the icon. He drew my attention to the symbolic significance of the shacks 16.On the pitfall of only focusing on apartheid violence, underestimating the multifaceted nature of township life and the agency of black South Africans, see Dlamini (2009) 
behind barbed wire - 'this is where people have been forced to live, having been homeless away from their homes', ${ }^{\prime 17}$ the colours are schmutzig [dirty, messy] to convey bad conditions; and he points out the deliberate similarity between the ribbones of Jesus and the corrugated iron shacks.

When I asked about the enraged facial expression, he referred me to Jesus' 'loud cry' in Hebrews 5:7 and Mark 15:37, stressing that the translation does not fully capture the original meaning of the 'brutal' sound of a sacrificial animal's death ruckle, associated with the slaughter of lambs in the Hebrew Bible. And he reminded me of the suffering servant in Isaiah who was 'despised and rejected....as one from whom others hide their faces' (Isaiah 53:3) (Louw 2014:243-266).

Brueggemann has enabled me to zoom out further and locate the subscript of Cross-Roads Jesus (Mt 27:45, quoting Ps 22:1) within the many 'dark Psalms' of lamentation. ${ }^{18}$ For him, the poetry of the lament psalm is a 'painful, anguished articulation of a move into disarray and dislocation' (Brueggemann 1984:20). These 'psalms of disorientation' - such as Psalms 13, $86,35,79,137,88,109$ - match in varying degrees the 'ragged disarray' of that season in (individual and communal) human life where one is confronted with 'hurt, alienation, suffering, and death', a season which evokes 'rage, resentment, self-pity, and hatred' (Brueggemann 1984:19). For him, these Psalms express a 'decisive move' in the 'life of faith' where the 'old, known world' is 'dismantled', the 'safe, reliable confidence in God's good creation' is relinquished, a movement that includes 'a rush of negativities' including 'shame, guilt, isolation, despair, and hostility'(Brueggemann 1984:20). I agree with Brueggemann (1984:11-12) that the connection between these Psalms and the 'Christian confession of crucifixion and cross' is very clear. And I resonate deeply with his prophetic application of these Psalms of disorientation to his own context by stressing that they are 'profoundly subversive of the dominant culture' (in society and church), which 'wants to deny and cover over the darkness we are called to enter', as reflected by widespread liturgical marginalisation of Psalms of lamentation (Brueggemann 1984:12, 51-52). ${ }^{19}$

Brueggemann's self-critical surfacing of the unflinchingly honest, impolite Jewish spirituality portrayed in the 'passionate poetry' of the Psalms of lamentation provides me with an undeniable, hospitable, biblical framing of CrossRoads Jesus. ${ }^{20}$

\section{7. 'Hulle is ontheim van hul heimat, hul woning'.}

18.The fuller Biblical context of the Matthew 27:45 subscript conveys more of Jesus desanitised lamentation that Louw's Cross-Roads icon so vividly attempts to 'resurrect': 'My God, my God, why have you forsaken me? Why are you so far from helping me, from the words of my groaning? O my God, I cry by day, but you do not answer; and by night, but find no rest' (Ps 22:1-2).

19.See also Moltmann's (2015:47) radical understanding of 'The Crucified God', including this telling statement: 'Even the disciples of Jesus all fled from their master's cross. Christians who do not have a feeling that they must flee the
crucified Christ have probably not yet understood him in a sufficiently radical way'. I explore Moltmann's understanding further within a forthcoming article on (white) hope and Black Christ.

20.I find it appropriate that another older, white, DRC dominee guided me in this regard. After my input on 'dark white work' at the 2018 Winter School of the
Stellenbosch Theological Faculty, Dr Coenie Burger pointed me to Brueggemann's Stellenbosch Theological Faculty
understanding of the Psalms.
In making sense of Louw's very unsettling crucifixion icon, I am also aided by James Cone's (2017:159) recent, fleshed out analogy between the 'lynching' of Jesus and the (literal and figurative) lynching of black Americans, typically by 'white Christians who claimed to worship the Jew lynched in Jerusalem'. Cone provides specific support for the troubling body language of Louw's Jesus figure by highlighting the similarity between 'Jesus' agonising final cry of abandonment from the cross' and 'the lynched victim Sam Hose's awful scream as he drew his last breath, "Oh, my God! Oh, Jesus"' (Cone 2017:161, citing Litwack 1998:281). ${ }^{21}$

The biblical roots of Louw's 'ugly' painting (Heb 5; Is 53; Mt 27; Mk 15, Psalms of lamentation) and the work of black theologians like Cone encourage me to stay longer with the extreme inner discomfort evoked by Cross-Roads Jesus. In the process, I have come to appreciate this icon as an imaginative, empathetic attempt to make more visible the depths of black (Christian) lamentation in a post-1994 South Africa that has not lived up to postapartheid expectations. Approaching Cross-Roads Jesus with the reverence, patience and humility required by religious icons has the counter-cultural, counter-intuitive potential to disrupt re-traumatising 'white denial' (ed. Henkeman 2018).

In my experience, this sorely needed disruptive potential can be increased by gazing at Cross-Roads Jesus through the lens of Black Christ. For me, this means bringing those two white Afrikaner politician-centurions (and everyone they represent) into the picture. It implies that someone like me is holding that long spear, poking into the ribs of the emaciated figure on the cross. While psalm-like lamentation takes place in the context of prayer to God, it also typically contains pretty strong language directed at (perceived) enemies. In terms of contextualised lamentation about ongoing structural violence, this 'enemy' language becomes Harrison's (2006) midnight cry, also directed at someone like me:

How could [your] government that professed to be Christian perpetrate such immoral deeds and inflict so much pain and suffering on [us fellow] countrymen simply because [we] were of another race, another colour, another creed? (p. 25)

Moreover, the 'awful scream' of Cross-Roads Jesus becomes black Dutch Reformed theologian Lekula Ntoane's agonised 'cry for life' in response to powerful and pervasive 'Calvinist' sanctioning of apartheid: 'Wallowing in it, as Black South Africans in the South African existential reality already do, they are soul defiled, physically raped and dehumanized' (Ntoane 1983:124, quoted in De Gruchy 1991:30). ${ }^{22}$

21.1 am indebted to a young DRC dominee, Helgard Pretorius, for alerting me to the highly relevant work of Cone and Shelly Rambo, as part of his own embodied highly relevant work of Cone
'wound work' (Pretorius 2018).

22.In the context of De Gruchy's (1991:30) profound, non-demonising critique of 'imperialist' 'Afrikaner Calvinism', he refers to Ntoane's statement as an expression of 'gut feelings'. See also Mofokeng (1983). 
In the South African context, I cannot imagine these loud cries for life and liberation not being accompanied by music. Given the prominence of $\mathrm{H}$. F. Verwoerd as a personification of the system of apartheid, it is quite likely that the angry struggle song 'Pasopa Verwoerd' will be toyi-toyied in front of those township shacks in Louw's painting - including the refrain 'Nantsi'ndodemnyama, Verwoerd' (repeated four times). ${ }^{23}$ At some point, the haunting 'Senzeni Na?' (repeated four times) will almost certainly feature, as it did at many hearings of the TRC. ${ }^{24}$ And the subscript of this Black-CrossRoad-Christ icon might well become: 'Our brothers and sisters in Christ, why have YOU forsaken us?' (repeated, at least, four times).

\section{Beyond apartheid, towards deep reconciliation}

I believe that this kind of merging of Black Christ and CrossRoads Jesus increases their potential to disrupt destructive denial amongst South Africans racialised as white and who dare to call ourselves Christians. On the other hand, the combination of these prophetic icons also makes it even more tempting to run away, to stay in a 'fragile', 'fatigued' DRC bubble.

From a facilitation point of view, I would therefore argue that more attention needs to be given in church circles to the cultivation of white capacity to work creatively and sustainably with the intense discomfort brought to the surface by religious icons such as Black Christ and CrossRoads Jesus. ${ }^{25}$

Central to this capacity is a rediscovery of the paradoxical good news portrayed by these icons. For in the midst of some unwelcome, embarrassingly persistent emotional resistance, I have come to experience Black Christ, ultimately, as a profound icon of embodied hope. Mediated by the undeserved acceptance and remarkable generosity of spirit of many black South Africans (such as Themba Lonzi, Edwin Arrison, Pumla Gobodo-Madikizela and Marcella Naidoo), I have gradually come to appreciate the Luthuli figure on the cross as a forgiving representative of the body of Christ. The liberating, purified Ubuntu of someone like Archbishop Tutu's 'Father, forgive them' has deepened my faith in the radically inclusive reach of the Gospel of Jesus, the Christ.

As a white South African follower of this Christ, I need, however, to position Cross-Roads Jesus right next to Black Christ. I am increasingly convinced that someone with my historically racialised position in South Africa today may

23.See Nkoala (2013) for more background on and analysis of these songs of hope and struggle'. The lyrics of Pasopa Verwoerd are Nantsi'ndodemnyama, Verwoerd (x4)/Pasopa nantsi'ndodemnyama, Verwoerd (x4)/ Nantsi'ndodemnyama, Verwoerd (x4). Translation: Here is the black man, Verwoerd (x4)/ Watch out here comes the black man, Verwoerd (x4)/ Here comes the black man, Verwoerd (x4).

24.The lyrics of Senzeni Na? are Senzenina? ( $x 4) /$ Sonosethu, ubumyama? (x4)/ Sonosethuyinyaniso? (x4)/Sibulawayo ( $x 4$ )/Mayibuye i Africa $(x 4)$ Translation: what have we performed? $(x 4) /$ Is our sin the fact that we are black? $(x 4) /$ Is our sin the truth? (x4)/We are being killed (x4)/Return Africa (x4) (in Nkoala 2013).

25.In my experience, this kind of cultivation requires a disciplined, daily commitment to a range of spiritual practices, for example, Centering Prayer and, especially, the Welcoming Prayer (www.contemplativeoutreach.org). Within the DRC white work process (footnote 3 ), we are exploring the suitability of these practices. only use the language of (asking for) forgiveness if I am also willing to remain sitting in the profound discomfort, distress, disorientation elicited by the Cross-Roads icon. ${ }^{26}$ For this enraged Jesus is not only protesting at the ongoing legacies of the systematic dehumanisation of apartheid and colonialism.

I also hear anger and frustration, especially amongst the younger Fallist generation, arising from post-1994 black forgiveness that has typically not been reciprocated with genuine white repentance - including a deep change of heart and a restitutional sharing of the fruits of structural injustice (Govier \& Verwoerd 2002; Swartz 2016). Cross-Roads Jesus also challenges me to refrain from a domesticating, delegitimising embrace of a smiling, grandfatherly, forgiving 'Arch' and 'Madiba'.

Framing Black Christ with the fiery anger of Cross-Roads Jesus furthermore prevents a premature identification with the centurion's awakening. The biblical description of the centurion as the first person to recognise Jesus' full stature (Mk 15:39) can indeed become a source of hope when contextually applied to Verwoerd. If the 'Man of Granite' can symbolically be given a 'heart of flesh', then any white South African has the potential to become 'woke'? However, CrossRoads Jesus also warns against a too convenient use of Jesus' '... for they do not know what they are doing'. Part of white work includes a willingness to "break the "ignorance contract"', ${ }^{27}$ to accept shared responsibility for what we could have and should have known (Verwoerd 2001).

For me, a critical feature of Black Christ is that it brings representatives of white South Africans explicitly into the picture. In the process, it also highlights the (lack of) real relationship between Verwoerd and Luthuli - how do you have a relationship with someone poking a spear into your side? No wonder there is no eye contact. But the icon also provides clues to what a 'woke', humanising relationship between those represented by Verwoerd and Luthuli might look like. People who look like me and share culturalreligious-political connections with the Verwoerd-centurion need to lay down the spear of white fragility and white fatigue, which is rubbing salt into the wounds of those represented by the Luthuli figure. We need to take off our armour of indifference and denial. ${ }^{28}$ We need to look the children and grandchildren of Luthuli in the eye, open the ears of our hearts, and in vulnerability, with humility, take up our daily, lifelong cross of restitutional responsibility as white Christians in South Africa. ${ }^{29}$

26.For a perpetrator-based reflection on the pitfall of asking too quickly for forgiveness, see Verwoerd and Little (2016).

27.I am indebted to another young DRC dominee, Wimke Jurgens, for this insight. He is a key participant in the white work process within the DRC (footnote 3 ) and used Steyn's (2012) work on the 'ignorance contract' in his first round of reflections with two colleagues, Jaco Botha and Helgard Pretorius (Jurgens, Botha \& Pretorius 2018). The themes of hope, forgiveness and awareness are developed further in my forthcoming article on (white) hope and Black Christ.

28.The theme of disrobing, becoming 'naked' before God, features strongly in contemplative spirituality (see Sölle 2001), and is connected to the larger theme of vulnerability and deep reconciliation (Verwoerd 2019b; Wale 2019).

29.For an encouraging, embodied example of (younger) white Afrikaans-speaking South Africans taking up this cross, see www.betereinders.co.za. See also Swartz (2016) for many examples of how to translate this challenge into practice as an ordinary citizen. 


\section{Acknowledgements}

The author thanks Daniel Louw, Klippies Kritzinger and Carel Anthonisson for feedback that improved this article.

\section{Competing interests}

The author has declared that no competing interest exists.

\section{Author's contributions}

I declare that I am the sole author of this research article.

\section{Ethical consideration}

This article followed all ethical standards for a research without direct contact with human or animal subjects.

\section{Funding information}

This research received no specific grant from any funding agency in the public, commercial or not-for-profit sectors.

\section{Data availability statement}

Data sharing is not applicable to this article as no new data were created or analysed in this study.

\section{Disclaimer}

The views and opinions expressed in this article are those of the author and do not necessarily reflect the official policy or position of any affiliated agency of the author.

\section{References}

Beyers, J., 2019, 'Reconstructing black identity: The Black Panther, Frantz Fanon and Achilles Mbembe in conversation', HTS Teologiese Studies/Theological Studies 75(4), a5469. https://doi.org/10.4102/hts.v75i4.5469

Biko, S., 2012, I write what I like, Picador, Johannesburg.

Boesak, A., 1984, Black and reformed: Apartheid, liberation and the Calvinist tradition Skotaville, Johannesburg.

Brueggemann, W., 1984, The message of the Psalms: A theological commentary, Augsburg Publishing House, Minneapolis, MN.

Church, C., Visser, A. \& Johnson, L.-S., 2004, 'A path to peace or persistence? The "single identity" approach to conflict resolution in Northern Ireland', Conflict Resolution Quarterly 21(3), 273-291. https://doi.org/10.1002/crq.63

Cone, J.H., 2017, The cross and the lynching tree, Orbis Books, New York, NY Davenport, T.R.H., 1986, South Africa: A modern history, Macmillan, Johannesburg.

De Gruchy, J.W., 1991, Liberating reformed theology: A South African contribution to an ecumenical debate, W.B. Eerdmans, Grand Rapids, MI.

De Gruchy, J.W., 2001, Christianity, art and transformation: Theological aesthetics and the struggle for justice, Cambridge University Press, Cambridge.

De Gruchy, J.W., 2006, Being human: Confessions of a Christian humanist, SCM Press, London.

De Gruchy, J.W., 2008, Icons as a means of grace, Lux Verbi, Wellington.

De Gruchy, J.W., 2019, 'Is it possible for a white, male South African to enter the kingdom of heaven?', 8th Steve De Gruchy Memorial Lecture, Cape Town, 30 April. DiAngelo, R., 2011, 'White fragility', International Journal of Critical Pedagogy 3, 54-70. Dlamini, J., 2009, Native Nostalgia, Jacanda Media, Johannesburg.

Douglas, K.A., 1994, The Black Christ, Orbis Books, Maryknoll, NY.

Dousemetzis, H., 2018, The man who killed apartheid: The life of Dimitri Tsafendas, Jacana Media, Johannesburg.

Edlmann, T., 2012, 'Division in the (inner) ranks: The psychosocial legacies of the border wars', South African Historical Journal 64(2), 256-272. https://doi.org/10. 1080/02582473.2012.661450
Edlmann, T., 2015, 'The lingering unspoken pain of the white youth who fought for apartheid', The Conversation, 02 September, viewed 12 September 2019, from https://theconversation.com/the-lingering-unspoken-pain-of-white-youth-whohttps://theconversation.com/t

Eyerman, R., 2018, 'Perpetrator trauma and collective guilt: My Lai', in E. Boynton \& P. Capretto (eds.), Trauma and transcendence: Suffering and the limits of theory, Fordham University Press, New York, NY.

Frankenberg, R., 1993, White women, race matters: The social construction of whiteness, University of Minnesota Press, Minneapolis, MN.

Flynn, J., 2015, 'White fatigue: Naming the challenge in moving from an individual to a systemic understanding of racism', Multicultural Perspectives 17(3), 115-124. https://doi.org/10.1080/15210960.2015.1048341

Gobodo-Madikizela, P., 2016, 'What does it mean to be human in the aftermath of mass trauma and violence? Towards the horizon of an ethics of care', Journal of the Society of Christian Ethics 36(2), 64-91. https://doi.org/10.1353/sce.2016.0030

Grant, J., 1989, White women's Christ and black women's Jesus: Feminist Christology and womanist response, Scholars Press, Atlanta, GA.

Govier, T. \& Verwoerd, W.J., 2002, 'The promise and pitfalls of apologies', Journal of Social Philosophy 33(1), 67-82. https://doi.org/10.1111/1467-9833.00124

Govier, T. \& Verwoerd, W.J., 2011, 'Responsibility and responsiveness', Praxis 13(20), 9-23. Harrison, R., 2006, The Black Christ: A journey of freedom, David Philip, Cape Town.

Henkeman, S.M. (ed.), 2018, Disrupting denial: Analysing narratives of invisible/visible violence and trauma, New Adventure Publishing.

Jansen, J.D., 2009, Knowledge in the blood: Confronting race and the apartheid past, UCT Press, Cape Town.

Jurgens, W., Botha, J. \& Pretorius, H., 2018, “"I am - the brutal thing itself”: A case study of confronting whiteness through "single identity work"', paper presented at the recognition, reparation, reconciliation: The light and shadow of historical trauma conference, Stellenbosch University, Stellenbosch, 05-08 December.

Kenney, H., 1980, Architect of apartheid: H.F. Verwoerd: An appraisal, Jonathan Ball, Johannesburg.

Kinghorn, J. (ed.), 1986, Die NG Kerk en apartheid, Macmillan, Johannesburg.

Klaassen, J.A., 2001, 'The taint of shame: Failure, self-distress, and moral growth', Journal of Social Philosophy 32(2), 174-196. https://doi.org/10.1111/0047-2786.00087

Kleinschmidt, H., (ed.), 1972, White liberation: A collection of essays, Spro-Cas, Johannesburg.

Kritzinger, K., 2008, 'Liberating whiteness. Engaging the anti-racist dialectic of Steve Biko', in C.W. du Toit (ed.), The legacy of Stephen Bantu Biko: Theological challenges, pp. 89-113, Unisa, RITR, Pretoria.

Krondorfer, B., 2015, 'Unsettling empathy: Intercultural dialogue in the aftermath of historical and cultural trauma', in P. Gobodo-Madikizela (ed.), Breaking cycles of repetition: A global dialogue on historical trauma and memory, pp. 90-112, Budrich, Opladen

Lentz, R. \& Gateley, E., 2003, Christ in the margins, Orbis Books, Maryknoll, NY.

Little, A. \& Scott, R., 2009, Give a boy a gun: From killing to peace-making, Darton, Longman \& Todd, London.

Little, A. \& Verwoerd, W.J., 2013, Journey through conflict trail guide: Introduction, Trafford Publishing.

Litwack, L.F., 1998, Trouble in mind: Black Southerners in the age of Jim Crow, Alfred Knopf, New York, NY.

Louw, D.L., 2014, Icons: Imaging the unseen, SUN Press, Stellenbosch.

Luthuli, A., 2006, Let my people go: The autobiography of Albert Luthuli, Tafelberg, Cape Town.

Margalit, A., 2002, The ethics of memory, Harvard University Press, Cambridge, MS.

Margalit, A., 2017, On betrayal, Harvard University Press, Cambridge, MS.

Meagher, R.E., 2014, Killing from the inside out: Moral injury and just war, Cascade Books, Eugene, OR.

Mofokeng, T.A., 1983, The crucified among the crossbearers: Towards a Black Christology, J.H. Kok, Kampen.

Moltmann, J., 2015, The crucified God, 40th anniversary edn., Fortress Press, Minneapolis, MN

Nkoala, S.M., 2013, 'Songs that shaped the struggle: A rhetorical analysis of South African struggle songs', African Yearbook of Rhetoric 4(1), 51-66.

Ntoane, L.R., 1983, A cry for life: An interpretation of 'Calvinism' and Calvin, J.H. Kok, Kampen.

Pretorius, H., 2018, 'Resurrecting wounds in the after-life of Apartheid', Public lecture at Vrije Universiteit, Amsterdam, 24 April.

Rambo, S., 2017, Resurrecting wounds: Living in the afterlife of trauma, Baylor University Press, Waco, TX.

Report of the Truth and Reconciliation Commission of South Africa, 1998, vols. 1, 4, Juta Press, Cape Town.

Rothberg, M., 2019, The implicated subject: Beyond victims and perpetrators, Standford University Press, Standford.

Schoeman, W.J., 2010, 'The racial discourse and the DRC: Looking through a descriptive empirical lens...towards a normative task', Acta Theologica 30(2), 130-151. https://doi.org/10.4314/actat.v30i2.67266

Sölle, D., 2001, The silent cry: Mysticism and resistance, Fortress Press, Minneapolis, MN. Steyn, M., 2001, Whiteness just isn't what it used to be, SUNY Press, New York, NY. 
Steyn, M., 2012, 'The ignorance contract: Recollections of apartheid childhoods and the construction of epistemologies of ignorance', Identities 19(1), 8-25. https:// doi.org/10.1080/1070289X.2012.672840

Swartz, S., 2016, Another country: Everyday social restitution, Bestred, HSRC Press, Cape Town.

Van der Westhuizen, C., 2016, 'Afrikaners in post-apartheid South Africa: Inward migration and enclave nationalism', HTS Teologiese Studies/Theological Studies 72(4), 1-9. https://doi.org/10.4102/hts.v72i4.3351

Van der Westhuizen, C., 2017, Sitting pretty: White Afrikaans women in postapartheid South Africa, University of KwaZulu-Natal Press, Pietermaritzburg.

Van Wyngaard, C., 2011, 'Post-apartheid whiteness and the challenge of youth 'Pornal for Youth and Theology 21(2), 23-34. https://do org $/ 10.1163 / 24055093-90000037$

Verwoerd, W.J., 1997, My winds of change, Ravan Press, Johannesburg.

Verwoerd, W.J., 2001, 'On our moral responsibility for past violations', Alternation 8(1), 219-242.

Verwoerd, W.J. \& Little, A., 2016, 'Public and private: Practitioner reflections on forgiveness and reconciliation', in C. Hundleby (ed.), Reasonable responses: The thought of Trudy Govier, pp. 148-173, University of Windsor, Windsor, Ontario.
Verwoerd, W.J. \& Little, A., 2018, 'Beyond a dilemma of apology: Transforming (Veteran) resistance to reconciliation in Northern Ireland and South Africa', in B. Krondorfer (ed.), Reconciliation in global context: Why it is needed and how it works, pp. 47-82, SUNY Press, New York, NY.

Verwoerd, W.J., 2018, 'Towards hospitality between enemies', in D.P. Veldsman \& Y. Steenkamp (eds.), Debating otherness with Richard Kearney: Perspectives from South Africa, pp. 287-306, AOSIS, Cape Town.

Verwoerd, W.J., 2019a, 'How do I stop running away from the kingdom of heaven?', Response to John De Gruchy's 8th Steve De Gruchy Memorial Lecture, Cape Town, 30 April.

Verwoerd, W.J., 2019b, Verwoerd: My Journey through Family Betrayals, Tafelberg, Cape Town.

Wale, K., 2019, 'Towards critical cultural openness: (In)Vulnerability in white student narratives of transformation in South Africa', Ethnic and Racial Studies 47(7) 1189-1207. https://doi.org/10.1080/01419870.2019.1642502

Williams, R.L., 2014, Bonhoeffer's Black Jesus: Harlem renaissance theology and ethic of resistance, Baylor University Press, Waco, TX.

Wolterstorff, N., 1987, 'The wounds of God: Calvin's theology of social justice', The Reformed Journal 37(6), 14-22. 